\title{
A Study on the Poetic Patterns in Laila Al-Atrash's Novel a Woman unlike Herself
}

\author{
Asmaa M. Al Zuraigat \\ Department of Arabic, College of Arts \\ Tafila Technical University, Tafila \\ Jordan \\ Hussein Hasan Zeidanin \\ Department of English, College of Arts \\ Tafila Technical University, Tafila \\ Jordan
}

\begin{abstract}
The present article addresses the poetics of narrative in A Woman Unlike Herself by Laila Al-Atrash. The two elements the article explores are the poetics of the title and the poetics of the language, which the writer used to support the narrative point of view in the novel. The different patterns of poetics used in the novel, the article finds, contribute to improving the poetic narration. As an experienced novelist and journalist, Al-Atrash placed her work within poetic contexts that manifest her creativity and prowess in the use of language and expression of the narrative point of view. The article also finds that the novel features the rebellion of the protagonist, Habibat AlEyn, against fear, illness, death and love. The novel touches upon the problematics of immigration using a concise intensive language that primarily relies on displacement, irony, hermeneutics and imageries. The language the writer used effectively expresses a troubled emotional and psychological state of the protagonist who encounters intolerable conditions. At the end, the protagonist becomes a woman unlike herself.
\end{abstract}

Keywords: Al-Atrash, A Woman Unlike herself, language, poetics, title

\section{Introduction}

The research paper investigates poetics patterns in Al-Atrash's novel, A Woman Unlike Herself. Poetics is perceived as a stylistic phenomenon with certain patterns that contribute to the construction of the linguistic and semiotic structures in the text. It as well helps express the writer's viewpoints, thoughts and sentiments, and instantiate her creativity, eloquence and literary prowess.

The paper employs an analytical descriptive approach to identify the poetic patterns used in the novel and enrich the critical canon of the Arab fiction studies. It comprises two sections, the first of which addresses the concept of poetics and its significance for the construction of literary genres. The second closely examines the effect of poetics on the interpretation of the text. The poetic patterns with which the paper is concerned are: poetics of the title, poetics of the language, and poetics of the irony.

The significance of this study springs from its investigation of a newly published novel. Not many critical reviews presented in symposiums or published in newspapers have been conducted on it. The excessive use of poetic techniques and language in the title and text is another attention grabber to the novel. The research topic is approached from the perspective of the literary theories of semiotics and poetics.

\section{Review of the Novel}

The writer utilized her historical and geographical readings for enriching the novel and harmoniously espousing reality and fantasy. The novel recollects the life story of Habibat Al-Eyn, the daughter of Arsalan Al Filzani who was a politician, diplomat. businessman and a head of a Pashtun tribe. He inherited wealth and chieftaincy from his great grandfather. Habibat Al-Eyn is the protagonist narrator of the novel. She was born in Mazar Sharif in Afghanistan. When Taliban seized power and established the Islamic Emirate of Afghanistan (IEF), Habibat's father, along with his wife and children, hastily migrated to London where the large fortune he held was devoted for their welfare and successful resettlement.

The topics the novel addresses pertain to the rebellion Habibat feels building inside after listening to her mother's story about a girl whose family never planned for her birth. The seeds of rebellion planted in her since then grow into a raging rebellion owing to the jealousy and envy she feels toward her sister Firdaus that is far more beautiful than her. 
The novel as well pertains to the dilemmas of immigration and the experience of living between a past and present homeland. Afghanistan, the birthplace of Habibat, lacked the welfare and security the family had in London where they believed they would encounter less unfairness, hardheartedness and degradation.

The protagonist meets a Palestinian young man, Munther Al-Shorafa, whom she falls in love with and eventually marries. Habibat's love story begins in London and ends in Amman. It is a love story between an Afghani girl, who was born to a Pashtun family in Afghanistan and studied Medicine in London, and a young Palestinian engineer displaced from Jerusalem. It is a sweeping love story about a girl who rebels against the traditions and culture of her tribe and becomes a woman in love. Soon she confronts a sense of self-estrangement and becomes a woman unlike herself due to a disappointing love experience, disabling illness, and gambling divorced husband. Habibat ends up at King Hussein Cancer Foundation and Center in Amman where she writes down her memoirs in a narrative style. Habiba plays the role of an omniscient narrator, and addresses her divorced husband and daughter as virtual readers of the memoirs. She reminds them of certain events and occurrences without observing the chronological order and continuity, "the narrative discourse the memoirs engender recounts certain attitudes and occurrences constituting the raw material of the novel. Instead of observing the chronological sequence of events, the narrator lets her thoughts and passions that belong to different time periods flowing in different directions" (Khalil 2019: 1). Habibat as the omniscient narrator of the novel retells her own autobiography in the form of memoirs, "I am Habibat Al-EynArsalan Al-Filizani... Immigration is my destiny. I am from a place that I do not know. I was born in a place; and my conscience was formed in another place; and now I am in a place that has never occurred to my mind" (Al-Atrash 2018: 11).

A Woman Unlike Herself is a novel about human love and fear. Habibat is unlike herself because of a disappointing love and disabling illness. She rebels against the traditions and customs of her family, tribe and society. Habibat is an immigrant girl who has never felt displaced or experienced life at refugee camps. Throughout her life, Habibat remains a woman unlike herself. Even after she is diagnosed with cancer, she steadfastly writes her autobiographical memoirs to her only daughter.

Al-Atrash in this novel intends to show that Habibat is living in an age that does not nurture love. Instead, it nurtures illness. Cancer in that sense signifies not only the illness inflicting Habibat but also the valueless world she is living in. Habibat can be perceived as a symbol for a woman overburdened with illness, masculinity, sway of illgotten money and oppressive regimes. She is the wife of that opportunistic Palestinian who eventually divorces her and plunges into gambling and dissipation. Habibat rebels against illness, and rejects death. She is portrayed as a unique woman with a strong will that helps her challenge the dualities of love and hate, illness and wellness, estrangement and belonging, fear and calm, failure and success.

\section{Theoretical Approach}

Russian formalists, e.g. Roman Jakobsonin Questions de poetique(1973), TzvetanTodorov in The Poetics of Prose(1971) and Mikhail Bakhtin in the Dialogical Principle (1984), proposed a new set of principles, formsand characteristics to render literary genres poetic. Jean Cohen (1986) defined poetics as the stylistics of literary genres, whereas Todorov (1971) conceived it as the abstract properties determining the uniqueness of literary works. Todorov emphasized that poetics and prose are double narratives, and that poetics signifies the creative use of language in any work of literature rather than the set of aesthetic rules or principles pertaining to poetry.

Poetics, in Todorov's belief, employs the social and psychological contexts of the literary text to study the linguistic structures, meaning and aesthetic values of the text. Abu Adib (1987), likewise, perceived poetics as intellectual, emotional or figurative constructs. The poetics of prose does not depend on using certain syllabic or grammatical structures. Rather it emanates from the figurative language, duality of replacement and invocation, ambiguity and multiplicity of signification, and the connotations associated with signifiers (Al-Ghuthami 1985). The sum of words used in a work of fiction signifies certain signs and symbols that can be understood and interpreted in different ways.

\section{Poetics of the Title}

Modernists concerned themselves with the significance of the title and its figurative relation with the text. The title is a medium between the writer and the reader as it determines how to read and interpret the text (Qatoos, 2001). Semiotically speaking, it has an organic relation with the text, and is the first threshold readers get exposed to and use to interpret the text. It provokes the curiosity of the reader (Ibn Hmaid, 1966) and helps identify the intentions and objectives of the text. The title suggests certain reflections and considerations to readers to help them delve into the world of the literary text. It as well imparts figurative significations to the whole text (Ibn Humaid 1966).

\footnotetext{
${ }^{1}$ As the novel is not translated from Arabic into English, all of the quotes taken from the novel are translated by the researchers.
} 
The interdependent relation between the title and text creates a horizon of expectation that arouses readers' search for meaning. The meaning the reader extracts from the text may converge with or diverge from the horizon of expectation, thus producing a completely unexpected reading.

As the first threshold of the text, the title is intended to reveal readers' perceptions and perspectives of the world. Roland Barthes, therefore, proposes that the titles saturated with cultural, political and social connotations should be investigated to show how they are ideologized and naturalized. Titles accordingly have ideological and aesthetic functions (Hamdawi, 2020). Writers usually infuse titles with semiotic signs to ensure multiple interpretations of texts.

In A Woman Unlike Herself, the writer dramatizes Habibat's rebellion, disappointing love, and sway of illness at different stages in her life. The transformational experiences of the protagonist undermine her self-constancy to the extent she becomes a woman unlike herself. Habibat discloses

I have grown into a woman unlike myself in your city. My other self lived elsewhere. It was the self of a rebellious girl who grew into a young woman in London. When we broke up, our love as well as myself got lost. That self has relentlessly overcome all obstacles. A struggle of two selves was taking me back to a childhood that was as changeable as the winter storms of a distant home, as cold as snow unceasingly falling on high mountains, and as warm as a short hot summer in a cycle of four seasons during which a climate quietly takes off its gown (Al-Atrash 2018: 12).

The conflicting significations embedded in the irony allow the reader to affirmatively or negatively interpret the title. While the novel opens with the bracket of rebellion on the part of an Afghani girl, it closes with the bracket of a struggle leading to a disappointing love and vain search for the self. The reader perceives negation as affirmation based on the contradictory readings the title evokes. The novel further suggests that the different aspects and states of the self are supposed to be congruous, "my other self lived elsewhere. It was the self of a rebellious girl.When we broke up, our love as well as myself were lost ". For anonymous reasons, the writer emulated the psychological disorder the Afghani physician, Habibat, has due to her illness and resettlement experience in Amman. Worse than that, her husband takes advantage of her powerlessness and dissipates her wealth on gambling. Using the simple present tense with the negative particle (not) suggests that the Afghani physician has relinquished her former self. The negative particle used in the title also denotes that Habibat does not anymore resemble herself at the present. If her former and present selves were similar, an accusative particle would be used with the simple present tense. The dissimilarity between Habibat and herself will last as long as her illness, distress and psychological disorder continue.

In another signification, the title alludes to The Witch of Portobello by the Brazilian novelist Paulo Coelho. In that novel, the female protagonist bends her rigid self to a malleable self in challenge of herself and environment to meet her aspirations. The emergent developments and transformations the protagonist undergoes help the reader foreshadow the end of the novel

The title of Al-Atrash's novel manifests her extensive vision and wide horizon. The implied or deleted subject in the title can be differently interpreted. An attempt to rephrase the title yields the following possible interpretations:

She is unlike herself.

She is completely unlike herself.

She is sometimes unlike herself.

She is not at all unlike herself.

Linguistically speaking, using the negative particle (not) in the title suggests two rhetorical patterns. On one hand, the simple present tense signifies a present or future state. The particle (not) in the title is used for an authorial intention. The use of (un) with an implicit present verb (is) and a preposition (like) means that the effect of negation does not extend to the past. Rather it describes the present and future state of the speaker at the moment of speaking. On that ground, it can be concluded that Habibat resembles her former but not her present self. However, it can be presumed that if the title is in the simple past, it will epitomize the transformation of the protagonist from one mental and psychological state into another as evidenced in her disclosure,

The woman you married is not Habibat Al-Eyen Arsalan Al-Filzani anymore. I am another woman that does not resemble her at all. That womanis rebellious but I am bound by the boundaries you have set. As you sometimes soften or erase the boundaries, I become idle enough not to cross them (AlAtrash 2018: 23).

Habibat has clearly turned into a different woman. She no longer resembles that rebellious woman. The abuse she endured from her Palestinian husband has completely changed her life, "as my love tolerated your oppression, your brutality and cruelty rose to unprecedented heights. You were a man I did not really know. You and I ended up 
taking different paths" (Al-Atrash, 2018, p. 23). The verb (resemble) suggests a difference between Habibat's former and current selves. However, the word (herself) with which the title closes semantically signifies the formation of a new self that shows the opposite of what it is hiding, creates a self unlike herself, and experiences reality with a fake identity.

In addition, the title implies such questions as how can a woman be unlike herself? And how can a woman depart from herself? It further embeds several semantic and mental displacements such as the dualistic oppositions of death and life, and childhood and youth. Driven by her experiences of displacement, illness and love, Habibat strives to save her medical and agricultural appliances company, which she co-established with her gambling husband, from bankruptcy. She manages to rescue the company though her heart is broken and body feeble. Frustrated over a failing marriage to a husband who squandered her money on gambling, Habibat becomes a woman unlike herself.

Examining the interrelation between Al-Atrash's novel and title finds that the title foreshadows the perspectives and implications the novel raises and conveys. Habibat is represented as a woman who is constantly searching for herself. In each time she believes she is reunited with herself, she discovers she no longer resembles herself.

The cover page holds a complementary relation with the title which can be perceived as a sign or symbol. The cover page together with the title forms a painting suggesting different questions, connotations and interpretations to readers. They as well perform a variety of different functions such as declaration, interrogation, and suggestion. The picture of a woman looking at herself in the mirror grabs attention and attracts readers to the cover page. It assumingly provides an accurate account of reality without any manipulation, modification or deception. However, the woman's picture breaks the reader's horizon of expectation when the mirror gives back a reflection that does not resemble the woman. The difference between the woman and her image in the mirror signifies the protagonist's rebellion and self-conflict.

Examining the relation of the title with the narrative text provides a basis for understanding the omniscient narrator, whom the novelist creates to speak her words, tell her story, and reveal her perspective to readers. Habibat is the omniscient narrator who tells her life-story in a memoir she writes to her daughter. In that story, she reflects upon the conflicts and circumstances that have transformed her into a woman unlike herself. She recalls occurrences pertaining to her rebellion against legacies, and her love that returned her to square one, a woman unlike herself. When she falls into the monstrous grip of cancer, she steadfastly challenges it by writing her own autobiography to her only daughter. In a monologue, Habibat states "should I begin my story with the rebellious girl living there? Or with an immigrant girl London admits for the fortune and legacy of her family? Or about the distresses and disappointments brought about by my love and marriage to you?" (Al-Atrasg 2018: 9) It is a violent love story that challenges all norms and customs, but fails at the thresholds of difference. The ill-health of Habibatis disproportionate with her strong will and rebellious self. Considering her illness, she gives up her dreams and resumes her struggle against an unknown tomorrow and a pain that will kill her aspirations within moments. After locks of hair fall into her hands, she declares the death of her femininity,

Now I wonder why I kept the secret of my illness from everyone? Was it a fear of death? I, therefore, wrote down my story on basis of my memories. I wrote it without planning or omission. I wrote the life-story of myself, homeland and you. I never distorted or beautified reality. I omitted nothing but what I inadvertently forgot. Most historians and biographers intentionally omit or skip certain details either for a fear of embarrassment or in pursuit for the pleasure and awards of the biographee. I am not pursuing any of that (Al-Atrash 2018: 228).

The title of this novel leaves no hope or reason for optimism. The general atmosphere of the novel cultivates constant tension and anxiety as fear prevails in conflict areas from where immigrants flee. Habibatis faced with an internal conflict between clinging to her Afghani identity and pursuing financial goals in exile. Realizing that her mission in life has not been fulfilled yet, she persistently races against time and resists illness. Her struggle at different fronts along with her raging love turns her into a woman unlike herself. The novel is constructed on the basis of dualistic oppositions between a pleasant past and unpleasant present, a heart beating with love and a heart broken and grieved by distresses, good health and ill-health. Habibat says "I resolved to tell my story because I am different. I realized I have been different since my childhood. They considered me a rebellious girl, but no one asked me why I rebelled against norms and traditions. I felt I was different" (Al-Atrash 2018: 228).

The form and content of the novel set conceptual structures and boundaries that contribute to multiplying the interpretations of the title. Habibat is viewed as a central character based on the narrative perspective of the text. She is picked to be the protagonist of the novel around whom the plot is built and the title revolves. The phrase "a woman unlike herself" is repeated many times in the novel which is based on the protagonist's biographical memoirs. 
The title unmasks the identity of a rebellious female protagonist who is different from other women. She has several conflicts inside her. She is struggling against desperation, frustration, deprivation and illness. The only means of survival for her is to challenge herself as well as others.

The title figuratively gives the glow of life to Habibat and her rebellion to enact the conflict of a contemporary man or woman with despotism, injustice, poverty, ignorance, displacement, love and hate. Hope or flee from home becomes the only means of salvation and emancipation for the people confronting such conflicts. She recounts that "Amman has its arms and doors wide open for us. Together we have achieved notable financial profits and benefits for years there. My strong will and resilience to illness have accounted for my successes so far" (Al-Atrash 2018, p. 232).

The title foreshadows the narrative end; and the multiple interpretations it signifies render the text poetic and rhetorical. The self Habibat has had is obsessed with childhood memories, coexistence, tolerance, love of homeland, and fear. The rhetorical gap between the signifier and the signified in the word (be unlike) is widened by the different significations it suggests. The word (self) manifests the nature of the relation the protagonist has held with herself. Understanding the relation between the title and the narrative is important for the reader to show how the title determines the narrative point of view, and how the text materializes it afterward.

The content of the text is apparently encoded in the title as well as the cover page to form the horizon of expectation that would introduce the reader to the narrative atmosphere and evoke suspense through a precise description of the protagonist, her daughter and divorcee. The protagonist is portrayed as a rebellious woman who does not resemble herself. As a central poetic pattern, the title signifies the text, and the text the title. Habibat recollects her memories of the past and conflicts of the present as she is lying on the healing bed at King Hussein Cancer Foundation and Center in Amman. She entrusts her secrets to her daughter, Manar, who is as rebellious as her mother. At the end, Al-Atrash declares closing the novel with an open ending. It is a novel enacting the pain of immigration Habibat and her husband have endured. The title further emulates the narrative theme: existence is death, and immigration uprooting (Zeidan 2018). It is narrated that "Habibat gradually adapted to life in your city. Amman has completely changed me. Cities encompass the souls of their inhabitants as much as springs the thirsty. Amman has changed me to the extent I no longer resemble myself" (Al-Atrash 2018: 5). The title is generally interwoven with the text "through a semantic and rhetorical relation" (Yacoub 2004: 15).

\section{Poetics of the language}

Imagery, metaphor and irony are significant literary devices that bring the language of prose in fiction closer to poetry. Barthe's analysis of the narrative language and its functions shows that sentence is not the only functional unit that should be studied in a narrative language. Other smaller functional units such as the word are more suggestive and indicative. The word, Barthes believes, constitutes the basic narrative structure (Barthes and Duisit 1975).

$\mathrm{Al}$-Atrash in A Woman Unlike Herself used a poetic concise language that is based on displacement and irony to represent the deep psychological distresses the protagonist is having. One pattern of the poetic language in this novel is the irony which Douglas.C. Muecke (1983) perceived as a sign signifying a sequence of different interpretations. It is also defined as "a rhetorical device that depends more on the cognitive relations between words than on rhythmic and structural relations" (Ibrahim 198:132). Irony accordingly has several functions among which multiplying interpretations, reconceiving the reader as a co-author but not a receiver of the text, and broadening the horizon of expectation to help readers produce meaning.

Irony in Al-Atrash's novel is instantiated by the raging rebellion of Habibat that lasts from childhood to adulthood. It culminates during her illness when she decides to keep the secret of her illness from everyone, and to write her own autobiography in the form of memoirs. Her fear to tell the truth dissipates at the moment she entrusts her secrets to her divorcee and daughter,

I am writing to retell a life story; I am not constructing a building with artistic designs and structures; and I am not writing a novel for fame. It is the story of a woman who no longer resembles the one who loved you and changed her life for you (Al-Atrash 2018: 8).

The narration offers a concise account of the protagonist-narrator's life. It is addressed to her opportunistic husband who "is displaced from the narrative by the power of her memory" (Masaood 2019: 9). The irony in this novel is intended to underscore the crucial mistake the protagonist makes when she loves and marries a man she has never trusted. Later she realizes that love must have blinded her from reality and truth, and writing is her only means of resistance, "writing is perceived as a release for emotions ... Mere reliance on emotions is inadequate to create a story. Eloquence is a talent ... I am a stormy sea of thoughts. Writing is the only means available to me for encountering you" (Al-Atrash 2018: 9). She reiterates"writing is my only means of resistance ... when your city relieved my displacement, we were at a long distance from each other. Each one of us took a different path. I determined to challenge life, rebel and triumph" (Al-Atrash 2018: 10). 
At a moment of self-reproach, the narrator condemns her Palestinian husband for the business relations he maintains with the Jews who dispossessed and displaced his people, and for the bankruptcy of her company.

In addition, the irony is meant to expose the narrator's rebellion against her greedy repulsive husband, and to relieve herself from the secret she cannot divulge to her daughter even in writing, " I am writing to tell herthe truth, what I feelbut my silence denies. Despite the pain suspicion might cause to her, it is more merciful than confronting her with reality" (Al-Atrash 2018: 7).

The poetic effect of the irony on the novel is realized when the narrator recollects an event or incident that completely departs from the reader's expectations. That is what happens when Habibat with a frail and ailing body rebels against illness and death. The fragility of her health does not hold her rebellion back as she expresses contradictory feelings of rejection, desperation and surrender, "I refused to give in, and kept resisting fear. He (the physician) emphasized the serious side effects of the new medicine, and gave me others to alleviate them. I took refuge in Allah from fear, and I grew stronger by faith" (Al-Atrash 2018: 6 - 7). She is paradoxically hiding her illness from everyone for fear of death. Still she is resisting by all means, including writing her autobiography in which she reflects upon herself, childhood and homeland. She realizes she would not be able to survive without having a strong will, "I resolved to retell my life story because I am different. I have been convinced of that since my childhood. They considered me a rebellious girl, but nobody asked me why I rebelled against the traditions and customs of my society. I felt I was different" (Al-Atrash 2018: 228).

Another ironic pattern in the novel is evident in the several transformations and changes the protagonist undergoes due to her experiences of immigration, love and illness. Habibat perceives immigration as a refuge from oppression, " the possibilities of survival and safety are what determine fateful decisions. We had no choice but immigration which was our only hope before the storm" (Al-Atrash 2018: 230). Then she reflects upon her resettlement and illness experience in Amman, "money is the only means through which I can ensure a decent life for my daughter. Amman, your city, has bestowed success upon me and took pity for my illness and weakness" (Al-Atrash 2018: 231). Only after she marries her gambling husband, she becomes a woman unlike herself. At the closing scene of the novel, Habibat mentions "my soul rejoices by doing her favorite things: handling what has been spoiled through work " (Al-Atrash 2018: 232). Habibat never surrenders to death or illness. She is like a soldier sent forth to a battle field tofight for either of the two ends: triumph or death. She has remained a woman unlike herself all her life. She never gives in until all the obstacles she is encountering are overcome.

The novel is built on a number of paradoxes that signify a number of contradictions between the past and present, a heart beating with love and a distressed love story, and an ailing body and a rebellious spirit. The narrator believes "nostalgia dims the brightness of the present" (Al-Atrash 2018: 12). Then she reveals that "I succeeded until my love and body let me down. Amid the contradiction of feelings, love and hate became alike. I could not know what path should I have taken in my race with life" (Al-Atrash 2018: 5).

The novel plunges the audience into the events as if they were happening to them, or occurring before them. Readers, therefore, identify themselves with the protagonist and the complex world she is living in. In addition, the novelist employs a narrative mode through which she speaks the mind and describes the flow of thoughts in the mind of the protagonist- narrator. Habibat uses an eloquent rhetorical language to speak her mind and reflect upon her illness, suffering and love. She relates, "I set sail to the unknown ... the chemistry of love never missesits target at the first sight" (Al-Atrash 2018: 12). It is an interesting description that grabs the reader's attention and leaves a lasting impression. She further says, "you cannot escape from a past your umbilical cord is tied to" (Al-Atrash 2018: 16). The language used in the novel is poetic enough to attract attention and entice the reader to the story the protagonist-narrator is telling. She figuratively perceives love as chemistry, and the past as a baby tied to the umbilical cord of his mother.

\section{Conclusion}

The reader of A Woman Unlike Herself is enticed by the narrative style, title and language. The present article identifies several patterns of poetics in the narrative text, namely the effect of the title on the poetics of the text and narration. The viewpoints are presented using a language as ironic as the title, and a special attention is given to the poetics of the title and its interdependent relation with the text. The article finds that an ironic paradoxical language is used to express the narrative perspective and open the text to multiple interpretations.

\section{References}

Abu Adib, Kamal. (1987). fyalsh'eryh [On Poetics]. Arab Research Institution, Beirut, Lebanon.

Al-Atrash, Laila. (2018). la tushbhdataha [A Woman Unlike Herself]. Al-Shurooq Dar for Publishing and Distribution, Jordan.

Al-Ghuthami, Abdullah. (1985). alkhaty'ehwaltakfyr[Sin and Atonement]. Cultural Literary Club, Saudi Arabia.

Barthes, Roland, and Duisit, Lione. (1975). An Introduction to the Structural Analysis of Narrative. New Literary History, 6(2): 237-272. 
Cohen, Jean. (1986). Bonyatallughhaalsh'eryah [The Language Poetics Structure], (M. Al-Wali and M. Al-Omari, Tans). Tobgal Publishing House, Casablanca.

Hamdawi, Jamil. (2020). Alsmyutiqawal-eununa [Semiotics and titling]. Al-Reef Dar for Electronic Publishing, Morocco.

Ibn Humaid, Ridha. (1966). Alkhtabalsh'eryalhdythmnaallughawyelaaltshkylalbasry [Modern Poetic Discourse: from Linguistic Discourse to Visual Modulation]. Fosul Journal. Vl. 51, 2(1): 32- 33.

Ibrahim, Nabilah. (1981). Almufarqh [Irony]. Fosul Journal, Vol. 7, 64(3): 12 - 22.

Khalil, Ibrahim. (Feb. 8, 2019). Laila Al-Atrashfy la tushbhdatahawalbahthdoona ufoq [Laila Al-Atrash in A Woman Unlike Herself: Search without Horizon]. Addustor Newspaper, Jordan.

Masaood, Meqdad. (Nov. 30, 2019). Suqutalqudwat w takhiralsard fi la tushbihdhatiha [The Fall of the Example and the Delay in the Narration in A Woman Unlike Herself]. Iraqi Communist Party.

Muecke, C. Douglas. (1983). Compass of Irony. Routledge

Qatoos, Bassam. (2001). symya' al'enwan [Semiotics of the Title]. Thought World Journal, Ministry of Culture, Jordan.

Todorov, Tzvetan. (1971). The Poetics of Prose. (R. Howard, Trans). Paris: Editions du Seuil.

Yacoub, Nasir. (2004). Allughatalshaeriatwatajaliyatuha fi alriwayatalearabia min 1970 - 2000 [Poetic Language and its Manifestations in the Arabic Novel from 1970 to 2000]. Al-Faris Publishing and Distributing House, Amman.

Zeidan, Badeyah. (April 9, 2019). la tushbhdatahaly-laylaalatrash [A Woman Unlike Herself by Laila Al-Atrash: Review]. Al-Ayam Newspaper. Palestine. 